\title{
Gambaran tingkat kecemasan pasien usia dewasa pra tindakan pencabutan gigi di Balai Prngobatan Rumah Sakit Gigi dan Mulut Manado.
}

\author{
${ }^{1}$ L. F. Joyce Kandou, ${ }^{1}$ P. S. Anindita, ${ }^{2}$ Melissa A. C. Mawa \\ ${ }^{1}$ Program Studi Kedokteran Gigi \\ ${ }^{2}$ Mahasiswa Program Studi Kedokteran Gigi \\ Fakultas Kedokteran Universitas Sam Ratulangi
}

\begin{abstract}
ABSTRAK
Kecemasan adalah hal yang wajar dialami semua orang yang dapat memberi pengaruh besar dalam perubahan perilaku. Rasa cemas merupakan respon normal terhadap peristiwa yang dianggap mengancam. Rasa cemas saat perawatan gigi telah menempati urutan ke-5 dalam situasi yang dianggap menakutkan. Fokus permasalahan adalah tingkat kecemasan pasien usia dewasa pratindakan pencabutan gigi. Penelitian ini bertujuan untuk mengetahui gambaran tingkat kecemasan pasien pra pencabutan gigi berdasarkan usia, jenis kelamin, pernah atau tidak pernah mencabut gigi, pra tindakan anestesi dan pasca tindakan anestesi. Penelitian ini merupakan penelitian deskriptif yang dilakukan pada tanggal 22 Juli sampai 9 Agustus 2013. Populasi dan sampel adalah pasien yang melakukan pencabutan gigi dengan usia 18-65 tahun dan bersedia menjadi responden. Teknik pengumpulan data menggunakan kuesioner Dental Fear Survey yang dimodifikasi menjadi 10 pertanyaan kemudian diberikan sebelum dan sesudah pasien dianestesi. Penilaian total skor tingkat kecemasan terbagi menjadi 3 kelompok yaitu rendah, sedang, tinggi. Hasil wawancara secara langsung yang diperoleh dari 47 pasien sebanyak 31 pasien merasa tidak cemas sebelum tindakan pencabutan gigi. Kesimpulannya pasien usia dewasa muda dan pasien yang tidak pernah menjalani tindakan pencabutan gigi memiliki tingkat kecemasan yang lebih tinggi, tingkat kecemasan pasien dewasa pra tindakan pencabutan pra anestesi adalah rendah dan tingkat kecemasan pasca anestesi adalah tinggi.
\end{abstract}

Kata kunci : Tingkat Kecemasan, Pencabutan gigi, Dewasa.

\begin{abstract}
Anxiety is common thing can happen to every body which can give big influence in behavior change. Dental anxiety has been ranked fifth among commonly feared situation. The focus of the problem is anxiety level in adult patients pre tooth extraction. The goals of this study are to know the dental anxiety level based on age, sex, have or haven't got tooth extraction, before anesthesia and after anesthesia

This research used descriptive method done on 22 July until 9 August 2013. Populations and samples are patients undergo tooth extraction age between 18-65 and willing to be respondent. Data collected through Dental Fear Survey questionnaires that had been modified into 10 questions given to patients before and after anesthesia. Total score assessment of dental anxiety level have been divided into 3 groups which are low, moderate and high.

The direct interview research resulted that among 47 patients there are 31 patients were not anxious pre tooth extraction. The conclusion was Young adults and patient who never went through tooth extraction have higher anxiety level, adult patients pre tooth extraction showed low level of anxiety before anesthesia and higher level of anxiety after anesthesia.
\end{abstract}

Keywords: Level of Anxiety, Tooth Extraction, Adult.

Korespondensi: Melissa A. C. Mawa, Program Studi Kedokteran Gigi, Fakultas Kedokteran Universitas Sam Ratulangi, Manado, Indonesia. E-mail: mel_mawa@yahoo.com 


\section{PENDAHULUAN}

Kecemasan adalah hal yang wajar dialami semua orang, yang dapat memberi pengaruh besar dalam perubahan perilaku. Rasa cemas merupakan respon normal terhadap peristiwa yang dianggap mengancam, atau terhadap tekanan yang dapat menyebabkan seseorang menjadi gelisah. Kadang kala kecemasan menjadi berlebihan sehingga menimbulkan ketakutan yang tidak rasional terhadap suatu hal tertentu. Contohnya cemas terhadap sesuatu hal yang belum pernah dialami sebelumnya, karena banyak mendengar cerita dari orang lain dapat menimbulkan pemikiran yang negatif .

Kecemasan sering dialami oleh seseorang yang akan menjalani perawatan gigi. Rasa cemas saat perawatan gigi telah menempati urutan ke-5 dalam situasi yang secara umum dianggap menakutkan. Kecemasan pasien dapat merugikan kesehatan gigi dan mulut, yang dapat menyebabkan rendahnya status kesehatan gigi dan mulut. Orang yang mempunyai pengalaman rasa cemas yang tinggi terhadap perawatan gigi memiliki tingkat kesehatan gigi dan mulut yang rendah. ${ }^{1-4}$

Bukti epidemiologis mengenai kecemasan pasien yang berdampak buruk pada perawatan kedokteran gigi dalam upaya meningkatkan kesehatan gigi dan mulut yaitu di Sri Langka 32\%, Inggris sebesar 24\%, di Fiji 28\%, di Republik Karibati 23\%, di India Barat 36\%, di Australia 14,9\% dan di Indonesia 9\%. ${ }^{4-8}$ Dalam literatur terdapat beberapa faktor yang dapat menimbulkan kecemasan pada pasien, yaitu: karakter pasien, takut akan rasa sakit, rasa sakit yang dulu pernah dirasakan khususnya pada masa kanakkanak, pengaruh kecemasan dari anggota keluarga yang mempengaruhi rasa cemas pasien. $^{5}$ Orang yang belum pernah menjalani tindakan bedah mulut, misalnya pencabutan gigi, pasti akan merasa lebih cemas dari pada orang yang sudah pernah. Selain itu ada juga pasien yang pernah memiliki pengalaman buruk saat pencabutan gigi, sehingga dapat mempengaruhi kecemasan pasien. ${ }^{6}$ Kecemasan pasien akan meningkat pada situasi-situasi tertentu, contohnya: hubungan komunikasi yang tidak baik antara pasien dan dokter/staf, etika yang tidak baik dari dokter dan staf, dokter dan staf yang marah, tidak ada rasa simpati kepada pasien, bau obat-obatan di ruang tunggu, jarum suntik dan teriakan dari pasien lain. Rasa cemas akan lebih meningkat pada waktu penyuntikan. ${ }^{7}$

Penelitian yang dilakukan di berbagai negara seperti di Australia, Inggris, Fiji, Republik Kiribati, dan India Barat tentang kecemasan pasien dewasa dalam tindakan perawatan gigi khususnya pencabutan gigi, dapat dilakukan dengan suatu alat ukur. Ada beberapa alat ukur yang dapat digunakan untuk mengetahui tingkat kecemasan orang dewasa terhadap perawatan gigi yang akan dilakukan, salah satunya adalah Dental Fear Survey (DFS). Alat ukur ini sangat berguna untuk mengetahui seberapa besar kecemasan pasien dewasa dalam bidang perawatan gigi. ${ }^{4-10}$ Penelitian ini bertujuan untuk mengetahui gambaran tingkat kecemasan pada usia dewasa pra tindakan pencabutan gigi di BP RSGM Manado.

\section{BAHAN DAN METODE}

Penelitian ini merupakan penelitian deskriptif. Jumlah sampel yang diteliti sebanyak 47 pasien usia dewasa, dengan teknik pengambilan sampel menggunakan total sampling. Pengumpulan data didapat dari hasil wawancara secara langsung kepada pasien menggunakan kuesioner Dental Fear Survey yang dimodivikasi. Pasien diwawancara pada pra tindakan pencabutan gigi pra anestesi dan pasca anestesi menggunakan DFS yang telah dimodifikasi sesuai dengan situasi dan kondisi 
HASIL PENELITIAN

Gambar 1. Distribusi subyek penelitian berdasarkan usia

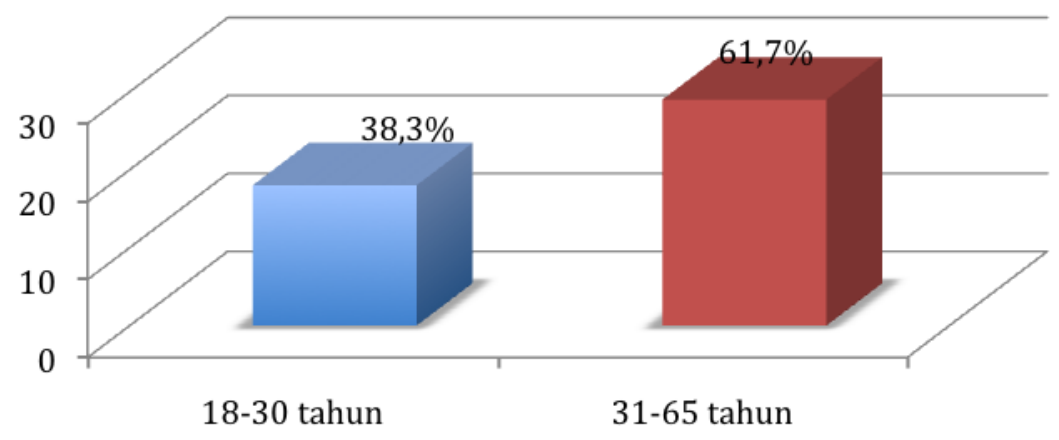

Gambar 2. Distribusi subyek penelitian berdasarkan jenis kelamin

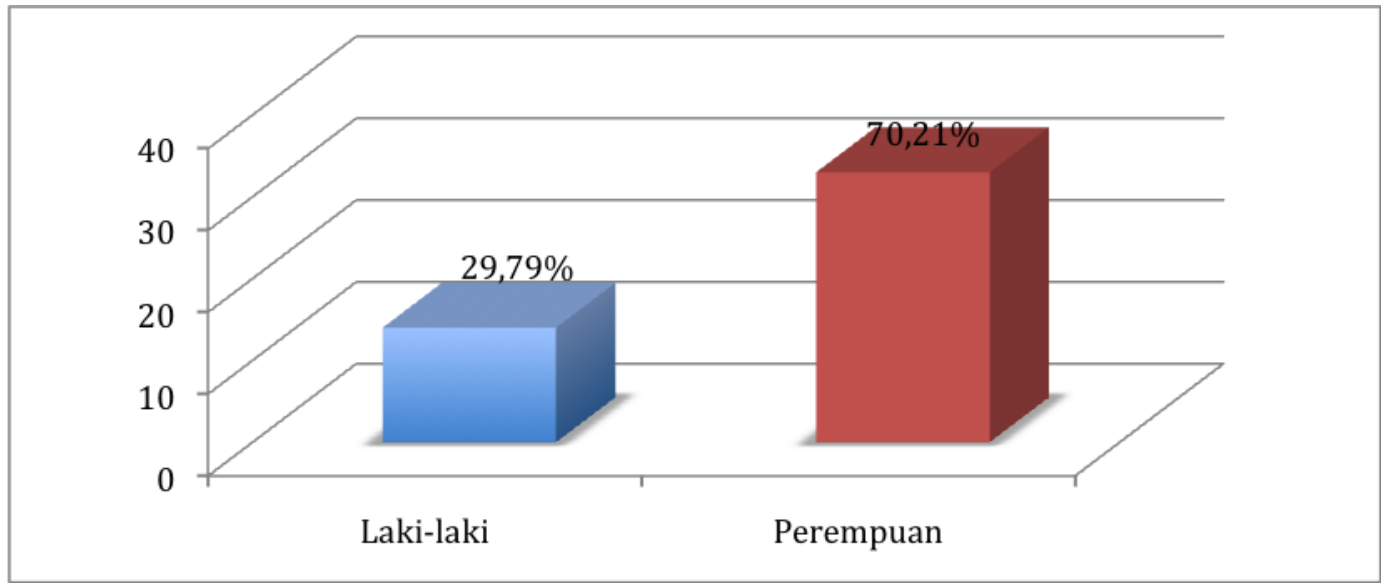

Gambar 3. Distribusi berdasarkan pernah atau tidak pernah menjalani pencabutan gigi 
Gambar 4. Distribusi tingkat kecemasan berdasarkan jenis kelamin.

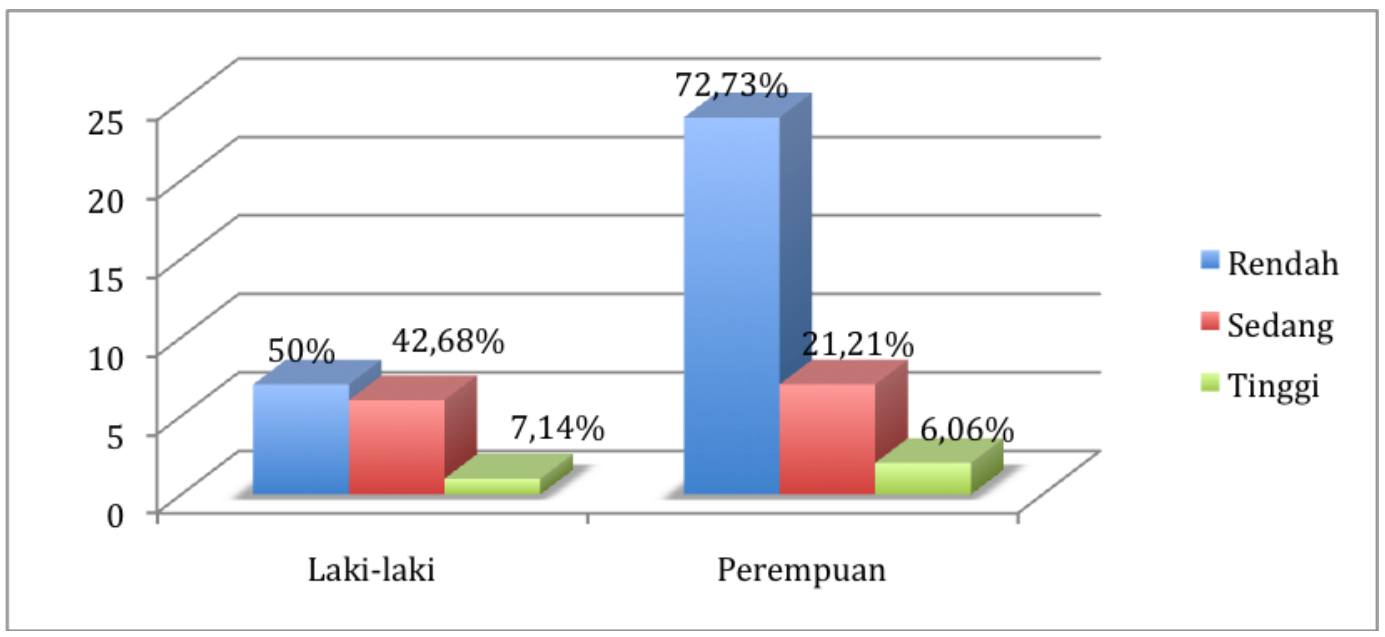

Gambar 5. Distribusi tingkat kecemasan berdasarkan usia

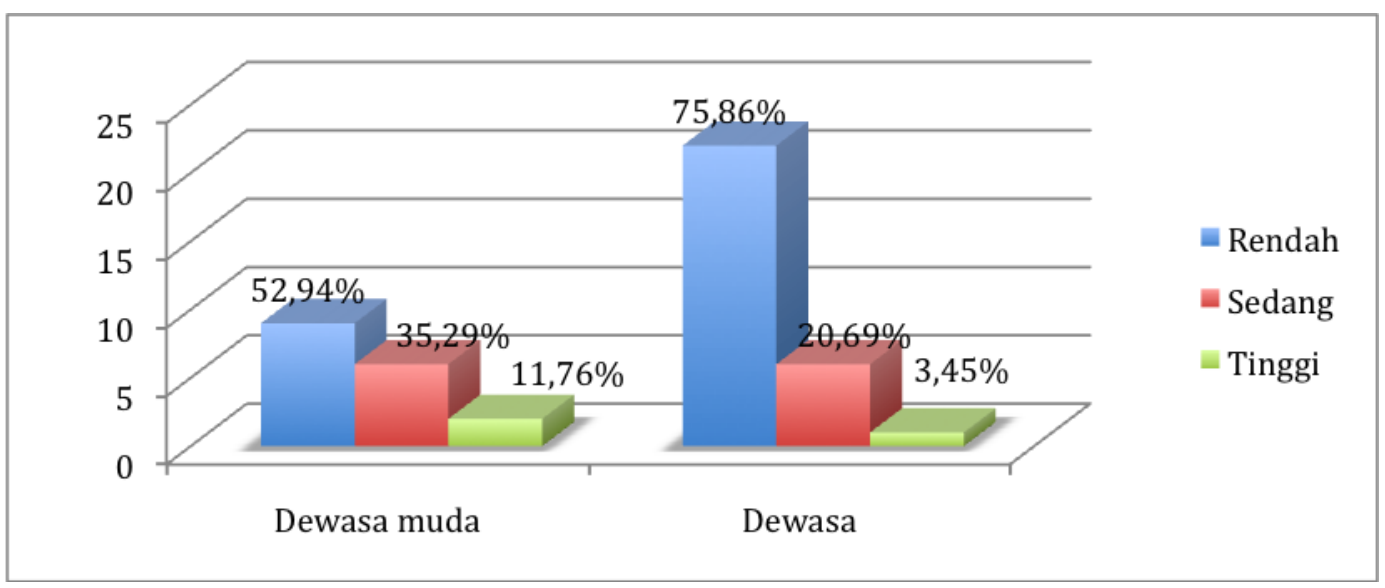

Gambar 8. Distribusi tingkat kecemasan berdasarkan pernah atau tidak pernah mencabut gigi

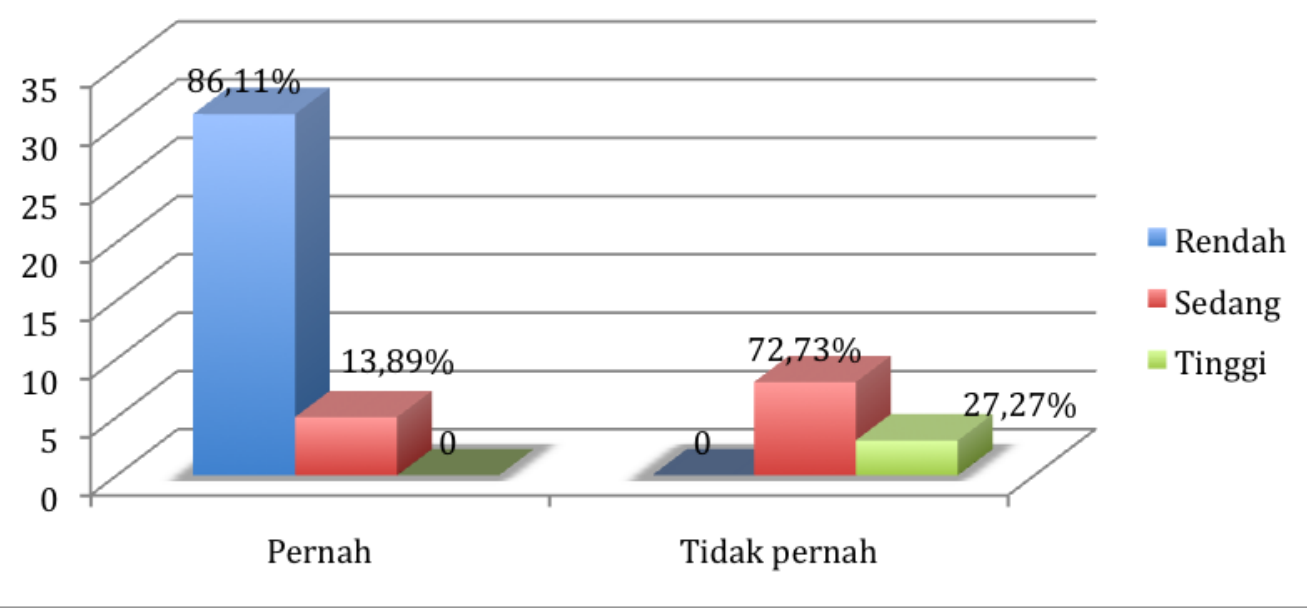


Gambar 9. Distribusi tingkat kecemasan sebelum dan sesudah anastesi

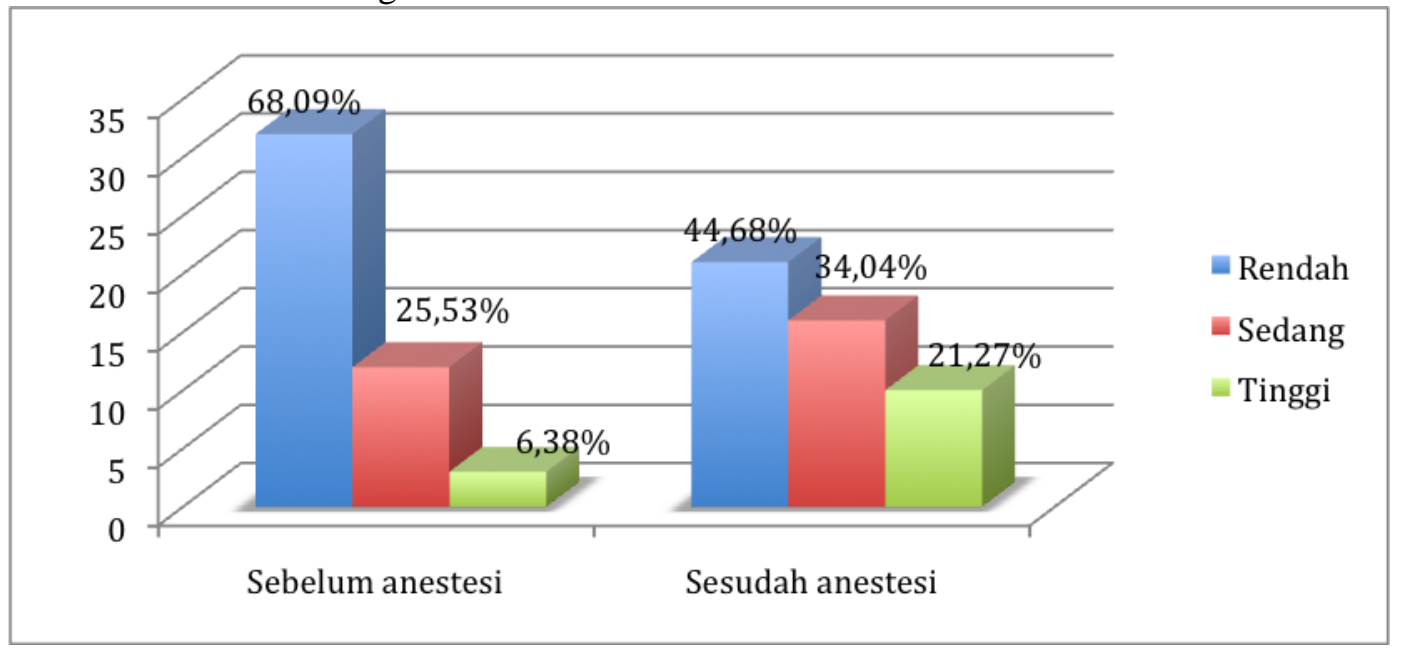

\section{PEMBAHASAN}

Hasil penelitian tentang tingkat kecemasan berdasarkan jenis kelamin (Gambar 6) menunjukkan dari 47 subyek penelitian, sebanyak 31 pasien mengalami tingkat kecemasan rendah pada pencabutan gigi. Sebagian dari mereka adalah perempuan. Umumnya kecemasan sering terjadi pada perempuan karena dari sudut pandang psikologis, perempuan lebih berpikir dengan perasaan dibandingkan laki-laki. Tidak begitu dengan penelitian yang dilakukan oleh Morse dan Takau menyatakan perbedaan kecemasan dalam jenis kelamin di Indonesia dan Argentina. Penelitian mereka menunjukan bahwa perempuan-perempuan di Indonesia dan Argentina memiliki tingkat kecemasan yang rendah dalam menghadapi pencabutan gigi dari pada laki-laki. Jenis kelamin merupakan salah satu faktor yang penting yang berhubungan dengan kecemasan pada pencabutan gigi. ${ }^{4-6}$

Distribusi tingkat kecemasan berdasarkan usia (Gambar 7) menunjukan bahwa pasien dewasa muda lebih merasa memiliki tingkat kecemasan sedang dari pada pasien dewasa. Pasien dewasa muda masih lebih labil dalam menghadapi suatu hal tertentu yang dapat membuat mereka tertekan, oleh karena itu banyak dari pasien dewasa muda yang lebih cemas dari pada pasien dewasa. Hal ini sesuai dengan penelitian yang dilakukan oleh Hoem et al di Universitas Tromso, Norwegia dimana usia dewasa muda lebih cenderung memiliki tingkat kecemasan sedang pada perawatan gigi khususnya dalam pencabutan gigi. ${ }^{28}$

Hal ini dapat berhubungan dengan faktor psikologis dalam proses menjadi dewasa. Pasien dewasa (31-65 tahun) bisa langsung menyesuaikan diri dengan mengatur pikiran untuk menjadi rileks. Usia dewasa memiliki kecenderungan untuk menggunakan kemampuan penyesuaian diri yang dipelajari baik melalui pengalaman menghadapi masalah kesehatan yang lebih serius atau dengan sengaja menghindari interaksi yang berpotensi negatif. Tetapi pada usia dewasa muda sering menghubungkan kecemasan dengan kecemasan yang berlebihan. ${ }^{26,27}$

Distribusi tingkat kecemasan berdasarkan pernah atau tidak pernah mencabut gigi (Gambar 8) menunjukan bahwa pasien yang sudah pernah melakukan pencabutan gigi memiliki tingkat kecemasan yang rendah sedangkan yang tidak pernah mencabut gigi memiliki tingkat kecemasan yang sedang dan tinggi. Semua pasien dengan tingkat kecemasan yang tinggi tidak pernah melakukan pencabutan gigi. Banyak alasan pasien untuk merasa cemas terutama pada pasien yang belum pernah menjalani tindakan pencabutan gigi, tetapi tidak menutup kemungkinan pada pasien yang sudah pernah mencabut tidak akan merasa cemas. Pengalaman buruk pasien dapat menjadikan alasan dari rasa cemas pasien yang sudah 
pernah menjalani tindakan pencabutan gigi. Hasil penelitian yang dilakukan oleh Gow di Inggris menunjukkan hal yang sama. Gow menyatakan bahwa rasa cemas pada pencabutan gigi dapat terjadi karena beberapa faktor yaitu rasa takut darah atau luka yang berdarah, pasien takut kesakitan, pasien yang belajar dari pengalaman anggota keluarga dan teman yang mengalami hal buruk ketika melakukan pencabutan gigi, pasien yang trauma karena pengalaman buruk yang dialami, dan karakter pasien. ${ }^{5,6}$

Distribusi tingkat kecemasan subyek penelitian sebelum dan sesudah anestesi (Gambar 9) memperlihatkan hasil penelitian sebelum anestesi banyak pasien dengan tingkat kecemasan yang rendah tetapi sesudah anestesi pasien yang berada pada kategori tingkat kecemasan rendah lebih sedikit. Hasil pada kategori tingkat kecemasan sedang sebelum anestesi karena pengaruh ruangan, operator dan melihat alat-alat untuk mencabut gigi lebih rendah dari pada kelompok sesudah anestesi. Kecemasan pada pencabutan gigi adalah wajar dan saat pasien belum dianestesi cenderung lebih sedikit karena belum diberikan tindakan anestesi lokal. Kecemasan yang dialami para pasien yang belum pernah menjalani pencabutan gigi ada 11 pasien, seluruh pasien yang belum pernah menjalani pencabutan gigi mengalami peningkatan rasa cemas (lampiran 4).

Rasa tidak cemas dapat berubah menjadi lebih tinggi ketika jarum suntik masuk ke mukosa sehingga terasa sakit. Rasa sakit dapat terlihat dari kerutan wajah pasien ketika ketika disuntikkan obat anestesi. Hasil penelitian ini sama dengan hasil penelitian Vassend dan Olav tahun 2005 di Australia tentang rasa sakit dan ketidaknyamanan dihubungkan dengan perawatan pencabutan gigi. Ketika operator menganestesi pasien akan merasa sakit dan tidak nyaman pada waktu operator menyuntikan jarum suntik masuk ke dalam mukosa pasien. Hal ini dapat memicu sistem saraf simpatis sebagai mekanisme pertahanan tubuh. Sistem simpatis ini mempersiapkan untuk menghadapi bahaya dan dapat memicu kecemasan pada subyek penelitian sehingga angka kecemasan

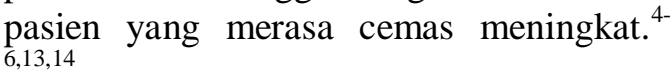

Keadaan pasien yang sangat cemas dapat dilihat pada gambar 9, ada 10 pasien $(21,27 \%)$ yang memiliki tingkat kecemasan tinggi tetapi salah satu dari pasien ini memiliki skor yang paling tinggi (Lampiran 4). Pasien yang memiliki skor yang paling tinggi adalah pasien laki-laki berusia 23 tahun yang tidak pernah mencabut gigi, pasien ini memiliki total skor 42 dari 50. Pasien ini mengalami syok hingga tidak sadarkan diri ketika selesainya anastesi blok mandibula. Kejadian ini menunjukan kecemasan tingkat tinggi adalah ketika seseorang percaya adanya sesuatu yang berbeda dan adanya ancaman. Perasaan ini dapat terlihat dari respon takut dan merasa tertekan. Ketika seseorang tiba pada tingkat kecemasan yang paling tinggi maka orang akan berhenti untuk memikirkan hal-hal yang rasional, dengan ciri-ciri respon fisik dari kecemasan tingkat tinggi adalah otot menjadi tegang, pernafasan meningkat dan gemetar. ${ }^{21}$

\section{SIMPULAN}

1. Distribusi tingkat kecemasan berdasarkan jenis kelamin menunjukkan lebih dari setengah subyek penelitian mengalami kecemasan yang rendah khususnya pada perempuan.

2. Tingkat kecemasan subyek penelitian pada usia dewasa adalah rendah

3 Tingkat kecemasan subyek penelitian pada yang pernah menjalani tindakan pencabutan gigi adalah rendah

4. Tingkat kecemasan subyek penelitian pada pra dan pasca anestesi menunjukkan bahwa pra anestesi kebanyakan pasien dengan kecemasan tingkat rendah.

\section{SARAN}

Penelitian ini bisa menjadi umpan balik bagi BP RSGM untuk meningkatkan pelayanan terutama dalam bidang pencabutan gigi dan Pentingnya informasi kepada pasien pra tindakan anestesi tentang kondisi yang akan dihadapi berkaitan dengan tindakan yang akan dilakukan pra tindakan pencabutan, sehingga diharapkan mampu menurunkan tingkat kecemasan 
pasien untuk keberhasilan tindakan pencabutan yang akan dilakukan.

\section{DAFTAR PUSTAKA}

1. JM Armfield. How Do We Measure Dental Fear and What Are We Measuring Anyway?. Oeal Health Prev Dent 2010; 8: 107-115

2. Sri Susilawati. Kesehatan Gigi dan Mulut Pengaruhi Kualitas Hidup Seseorang. Bandung. 2012. (Cited 2013 April 14, 2013) Available From: URL: http://www.unpad.ac.id/2012/10/kesehat an-gigi-dan-mulut-pengaruhi=kualitashidup-seseorang/

3. Raghad. T, Laurence L.W. Dental Anxiety: Causes, Complication and Management Approches. Journal Of Minimum Intervention In Dentistry. 2009; 2 (1)

4. Zac M, Aleva F. T. Dental anxiety in Fiji. Pasific Public Health 2 no 1. 2004.

5. Vassend, Olav. Anxiety, Pain and Discomfort Associated with Dental Treatment. Behavior Research and Therapy, 2005, 31. 7: 659-666.

6. Mike G. Dental Anxiety, Fear and Phobia. Dentistry 2011 juni 1:37 (col 1).

7. Morse Z. Dental Anxiety is very high in the Republic of Karibati. South Pasific Study 2007 1: 28 (col 1).

8. R Niadu. Dental Anxiety in a Sample of West Indian Adults. West Indian Med J 2010; 59(5):567.

9. JM Armfield, AJ Spencer, JF Stewart. Dental fear in Australia: who's afraid of the dentist?. Australian Dental Journal 2006;51:(1):78-85.

10. Ebtissam M, Hoda Abdel Latif. Assesment of Dental Fear and Anxiety Among Adolecent Females in Riyadh, Saudi Arabia. Saudi Dental Journal. 2002; 14(2): 77-81.

11. Oxford Dentistry Dictionary [book on IPAD]. $1^{\text {st }}$ ed. New York (NY): Oxford University Press; 2010.
12. Singgih D, Yulia S. Psikologi Perawatan: Kecemasan. Jakarta: Libri; 2012 h 42- 50

13. Jakola S, Alanen P, Rautava P. Dental fear: One Single Clinical Question Measurment. The Open Dentistry Journal 2009, 41.3:161-166.

14. Ratih P. Pengertian Kecemasan. Jakarta. 2010. (Cited April 22 2013). Available From: URL: www.psikologi.or.id/mycontents/uploads/ 2010/05/pengertian-kecemasananxiety.pdf

15. Khan P, Fawcett J. The Encyclopedia of Phobias, Fears, and Anxieties. 3th ed. New York: Facts on File; 2008 p 176-178

16. Moore UJ. Principles of Oral and Maxillofacial Surgery. $5^{\text {th }}$ ed. USA; Blackwell Science; 2001 p 67-83.

17. Oktay A E, Kocak M M. The Role of Age, Gender, Education and Experiences on Dental Anxiety. Departemen of Conservative Dentistry and Endodontics 2009; 51: 145-148.

18. Dailey Y, Humphris G, Lennon M. The Use of Dental Anxiety Questionnaries: a Survey of a Group of UK dental Sebelumctitioners. British Dental Journal 2001; 190(8):450-453.

19. Marginean I, Filimon L. Dental Fear Survey: a validation study on The Romanian Population. Journal of Psychological and Educational Reaserch 2011; 19(2): 124-138.

20. Claire G W. Mental Health Concepts. Fifth ed. New York: Thomson Learning; 2002 p 114-121

21. Mehboob B, Khan Ehtesham, Khan M. Dental anxiety Scale in Exodonxia Patient. Journal of Khyber Collage of dentistry.. 2011; 1(2):58-64

22. Wetsch WA, Pircher I, Lederer W, et al. Preoperative stress and anxiety in day-care patients and inpatients undergoing fasttrack surgery. British Journal of Anaesthesia 2009; 103(2):199-205. 
22. Klenknecht RA, Thorndike RM, McGlynn FD, et al. Factor analysis of dental fear Survey with cross-validation. J Am Dent Assoc 1984;108(1):59-61.

23. Nair A M, Shankarapillai R. The Dental Anxiety Levels Associated With Surgical Extraction of Tooth. International Journal of Dental Clinics 2009:1(1):20-23

24. Wainer A. The Fearful Dental Patient: A Guide to Undertanding and Managing. 2 ed. New York; Facts on File; 2009 p 203 204

25. Paul C, Keith H, Philip S, Elizabeth T. Master Dentistry Volume One.2 ed. Philadelphia: Elsevier; 2008 p 97

26. Jason M. How Do We Measure Dental Fear and What Are We Measuring?. Oral Health Prev Dent 2010; 8: 107-115.

27. Wainer A. The Fearful Dental Patient: A Guide to Understanding and Managing. 1st ed. Boston: Wiley Blackwell. 2011 p 212-213

28. Hoem et al. Clinical Management of Adult Patient with Dental Anxiety. International Journal of Dental Clinics 2012:6(1):29-34 